\title{
Correction to: Contribution of major food companies and their products to household dietary sodium purchases in Australia
}

Daisy H. Coyle ${ }^{1 *}$, Maria Shahid', Elizabeth K. Dunford ${ }^{1,2}$, Cliona Ni Mhurchu ${ }^{1,3}$, Sarah Mckee ${ }^{4}$, Myla Santos ${ }^{4}$, Barry M. Popkin', Kathy Trieu', Matti Marklund ${ }^{1,5}$, Fraser Taylor ${ }^{1}$, Bruce Neal ${ }^{1}$ and Jason H. Y. Wu ${ }^{1}$

\section{Correction to: Int J Behav Nutr Phys Act 17, 81 (2020) https://doi.org/10.1186/s12966-020-00982-z}

Following publication of the original article [1], the authors identified errors in Table 2 and Table 3. The correct tables are given below.

The original article [1] has been corrected.

\section{Author details}

'The George Institute for Global Health, Faculty of Medicine, UNSW, Level 5, 1 King St Newtown, Sydney, Australia. ${ }^{2}$ Department of Nutrition, The University of North Carolina at Chapel Hill, Chapel Hill, USA. ${ }^{3}$ National Institute for Health Innovation, The University of Auckland, Auckland, New Zealand. ${ }^{4}$ Nielsen, Sydney, Australia. ${ }^{5}$ Friedman School of Nutrition Science and Policy, Tufts University, Boston, MA, USA.

Published online: 04 December 2020

\section{Reference}

1. Coyle, et al. Contribution of major food companies and their products to household dietary sodium purchases in Australia. Int J Behav Nutr Phys Act. 2020;17:81. https://doi.org/10.1186/s12966-020-00982-z.

\footnotetext{
The original article can be found online at https://doi.org/10.1186/s12966020-00982-z.

* Correspondence: dcoyle@georgeinstitute.org.au

${ }^{1}$ The George Institute for Global Health, Faculty of Medicine, UNSW, Level 5,

1 King St Newtown, Sydney, Australia
}

(C) The Author(s). 2020 Open Access This article is licensed under a Creative Commons Attribution 4.0 International License, which permits use, sharing, adaptation, distribution and reproduction in any medium or format, as long as you give appropriate credit to the original author(s) and the source, provide a link to the Creative Commons licence, and indicate if changes were made. The images or other third party material in this article are included in the article's Creative Commons licence, unless indicated otherwise in a credit line to the material. If material is not included in the article's Creative Commons licence and your intended use is not permitted by statutory regulation or exceeds the permitted use, you will need to obtain permission directly from the copyright holder. To view a copy of this licence, visit http://creativecommons.org/licenses/by/4.0/. The Creative Commons Public Domain Dedication waiver (http://creativecommons.org/publicdomain/zero/1.0/) applies to the data made available in this article, unless otherwise stated in a credit line to the data. 
Table 2 Characteristics and contributions of the top 10 food companies contributing to Australian household purchases of sodium from packaged foods and beverages

\begin{tabular}{|c|c|c|c|c|c|c|c|}
\hline \multirow{2}{*}{$\begin{array}{l}\text { Company } \\
\text { rank }^{1}\end{array}$} & \multirow{2}{*}{$\begin{array}{l}\text { No. of } \\
\text { unique } \\
\text { products }\end{array}$} & \multirow[b]{2}{*}{$\begin{array}{l}\text { Total } \\
\text { weight of } \\
\text { products } \\
\text { purchased } \\
\text { (g/d per } \\
\text { capita) } \\
\text { Mean }^{2}\end{array}$} & \multicolumn{2}{|c|}{ Sodium (mg/d per capita) } & \multirow[b]{2}{*}{$\begin{array}{l}\text { Mean } \\
\text { purchase- } \\
\text { weighted } \\
\text { sodium } \\
\text { content } \\
(\mathrm{mg} / 100 \\
\mathrm{g})^{3}\end{array}$} & \multicolumn{2}{|c|}{ Contribution to total weight of sodium purchases } \\
\hline & & & Mean $^{2}$ & $\begin{array}{l}\text { Median (25th to 75th } \\
\text { percentiles) }\end{array}$ & & $\begin{array}{l}\text { Total } \\
(\%)\end{array}$ & $\begin{array}{l}\text { Top } 3 \text { food categories contributing to sodium } \\
\text { purchases }\end{array}$ \\
\hline 1 (Retailer) & 2406 & 74 & 156 & $15(0-166)$ & 386 & 15 & Processed meat (19\%); Cheese (14\%); Bread (11\%) \\
\hline 2 (Retailer) & 2313 & 84 & 138 & $56(9-180)$ & 302 & 12 & Processed meat (19\%); Cheese (15\%); Bread (14\%) \\
\hline 3 (Retailer) & 2317 & 94 & 128 & $65(14-169)$ & 267 & 12 & Processed meat (17\%); Bread (17\%); Cheese (15\%) \\
\hline 4 & 163 & 9 & 42 & $21(6-53)$ & 581 & 4 & $\begin{array}{l}\text { Bread (80\%); Processed meat (18\%); } \\
\text { Cakes, muffins and pastries ( } 2 \%)\end{array}$ \\
\hline 5 & 268 & 10 & 39 & $19(7-47)$ & 505 & 3 & $\begin{array}{l}\text { Bread (62\%); Mayonnaise and salad dressings (15\%); } \\
\text { Cakes, muffins and pastries (7\%) }\end{array}$ \\
\hline 6 & 536 & 14 & 36 & $24(10-47)$ & 321 & 3 & Vegetables (34\%); Sauces (29\%); Processed fish (22\%) \\
\hline 7 & 174 & 7 & 32 & $18(6-41)$ & 434 & 3 & Biscuits/cookies (98\%); Crisps and snacks (2\%) \\
\hline 8 & 535 & 7 & 26 & $16(6-32)$ & 448 & 2 & $\begin{array}{l}\text { Sauces (79\%); Herbs and spices (10\%); Chocolate and } \\
\text { sweets (6\%) }\end{array}$ \\
\hline 9 & 432 & 5 & 25 & $14(4-32)$ & 359 & 2 & $\begin{array}{l}\text { Spreads and dips (58\%); Chocolate and sweets (13\%); } \\
\text { Biscuits/cookies (13\%) }\end{array}$ \\
\hline 10 & 216 & 28 & 21 & $11(4-25)$ & 492 & 2 & $\begin{array}{l}\text { Crisps and snacks (74\%); Soft drinks (14\%); Biscuits/ } \\
\text { cookies (7\%) }\end{array}$ \\
\hline Others & 17,356 & 303 & 490 & $429(271-637)$ & 383 & 42 & \\
\hline
\end{tabular}

${ }^{1}$ Rank = Companies are ranked in order of their contribution to the total weight of sodium purchased by Australian households, from highest to lowest. Results for the top 10 companies are shown separately, with the remaining 1319 companies summed together to simplify data presentation. ${ }^{2}$ Standard error (SE) for mean weight of products purchased ( $\mathrm{g} / \mathrm{d}$ per capita) and sodium (mg/d per capita) not displayed as SE $\leq 0.1$ for each mean value. ${ }^{3}$ Purchase-weighted sodium content $(\mathrm{mg} / 100 \mathrm{~g})$ : weight of sodium $(\mathrm{mg})$ divided by the total weight $(\mathrm{g})$ of products purchased (package size $\mathrm{x}$ quantity sold in 2018 ). ${ }^{4} \%$ contribution of each of the top 3 food categories were calculated as a total of all sodium purchases within each company

Table 3 Major packaged food and beverage categories contributing to Australian household purchases of sodium

\begin{tabular}{|c|c|c|c|c|c|c|c|}
\hline \multirow{2}{*}{$\begin{array}{l}\text { Food } \\
\text { category } \\
\text { rank }^{1}\end{array}$} & \multirow[t]{2}{*}{ Food category } & \multirow[b]{2}{*}{$\begin{array}{l}\text { Total } \\
\text { weight of } \\
\text { products } \\
\text { purchased } \\
\text { (g/d per } \\
\text { capita) } \\
\text { Mean }^{2}\end{array}$} & \multicolumn{2}{|c|}{ Sodium (mg/d per capita) } & \multirow[b]{2}{*}{$\begin{array}{l}\text { Mean } \\
\text { purchase- } \\
\text { weighted } \\
\text { sodium } \\
\text { content } \\
(\mathrm{mg} / 100 \\
\mathrm{g})^{3}\end{array}$} & \multirow{2}{*}{$\begin{array}{l}\text { Contribution } \\
\text { to total } \\
\text { weight of } \\
\text { sodium } \\
\text { purchases } \\
\text { (\%) }\end{array}$} & \multirow{2}{*}{$\begin{array}{l}\text { HFP } \\
\text { proposed } \\
\text { target } \\
\text { (Yes/No) }\end{array}$} \\
\hline & & & Mean $^{2}$ & $\begin{array}{l}\text { Median } \\
\text { (25th to 75th percentiles) }\end{array}$ & & & \\
\hline 1 & Processed meat & 26 & 148 & $108(49-194)$ & 703 & 14 & Yes \\
\hline 2 & Bread & 31 & 129 & $102(53-175)$ & 451 & 12 & Yes \\
\hline 3 & Sauces & 16 & 124 & $98(53-160)$ & 986 & 11 & Yes \\
\hline 4 & Cheese & 15 & 110 & $85(48-143)$ & 736 & 10 & Yes \\
\hline 5 & Processed vegetables & 40 & 66 & $41(20-80)$ & 212 & 6 & No \\
\hline 6 & Biscuits/cookies & 14 & 58 & $43(22-76)$ & 422 & 5 & Yes \\
\hline 7 & Milk & 124 & 54 & $39(18-74)$ & 45 & 5 & No \\
\hline 8 & Crisps and snacks & 7 & 44 & $30(13-59)$ & 633 & 4 & Yes \\
\hline 9 & Edible oils & 10 & 43 & $30(13-57)$ & 409 & 4 & No \\
\hline \multirow[t]{2}{*}{10} & Spreads and dips & 6 & 38 & $26(11-48)$ & 730 & 3 & No \\
\hline & Others & 347 & 317 & $272(181-398)$ & 218 & 27 & - \\
\hline
\end{tabular}

${ }^{1}$ Rank = Food categories are ranked in order of their contribution to the total volume of sodium purchased by Australian households, from highest to lowest. Results for the top 10 food categories are shown separately, with the remaining 57 food categories summed together to simplify data presentation. ${ }^{2}$ Standard error (SE) for weight of products purchased ( $\mathrm{g} / \mathrm{d}$ per capita) and sodium (mg/d per capita) not displayed as SE $\leq 0.1$ for each mean value. HFP, Healthy Food Partnership. ${ }^{3}$ Purchase-weighted sodium content $(\mathrm{mg} / 100 \mathrm{~g}$ ): weight of sodium $(\mathrm{mg})$ divided by the total weight $(\mathrm{g})$ of products purchased (package size $\mathrm{x}$ quantity sold in 2018) 